\title{
Medical Managements of Musculoskeletal Diseases in Shipbuilding Industry
}

\author{
Jong-Eun Kim, Young-Ki Kim, Dong-Mug Kang \\ Department of Occupational and Environmental Medicine, Pusan National University, \\ Yangsan Hospital, Yangsan, 626-770
}

\begin{abstract}
Objective: This study is to understand medical management method in shipbuilding industry. Background: In shipbuilding industry, medical management for prevention of work-related musculoskeletal diseases due to limitations of engineering measures may be important measure. Results: Medical management of musculoskeletal diseases can be divided into primary, secondary, tertiary preventions. Primary preventions consist of symptom survey, appropriate work placement with work capacity evaluation, health promotion. Second preventions are early detection of symptomatic patient and appropriate treatment. Tertiary preventions are rehabilitation treatment and early return-to-work by return-to-work evaluation. In addition, patients with psychological counseling for emotional problems are needed. Conclusion: Medical management measures such as improving the work environment to be made are expected to exert greater effects.
\end{abstract}

Keywords: Work-related musculoskeletal disease, Shipbuilding industry, Medical management, Return-to-work

\section{Introduction}

직업성 근골격계 질환은 1998 년 이후로 지속적으로 증가 하여 2009년에만 6,222명이 산재승인을 받아 전체 업무 상 질병 승인자의 $71.3 \%$ 를 차지하였다. 그리고 2009년 산 업재해로 인한 직접적인 경제적 손실이 3 조 5천억 원, 직 · 간접 손실을 포함한 연간 경제적 손실 추정액은 17 조 원에 달해(Ministry of employment and labor, 2010), 이러한 측면에서 근골격계 질환 때문에 발생하는 사회적 비용 손실 은 상당하다고 볼 수 있다. 그 중에서 조선업은 특히 근골격 계 질환이 다발하는 업종으로서 미국은 조선업종에서 근골 격계 질환의 발생률이 만 명 당 132.9 로서 전체 업종 평균 인 26.3보다 높은 것으로 보고된 바가 있다(U.S. Bureau of Labor Statistics, 2001). 그리고 우리나라에서도 조선 업종에서 근골격계 증상 유병률이 높은 것으로 보고되었다 (Kim et al., 2003; Kim et al., 2004).
이렇게 조선업종이 근골격계 질환의 발생위험이 큰 이유 는 취급장비가 중량물인 경우가 많고, 선행의장 등이 진행된 좁은 블록 안에서 극도의 불안정한 자세로 작업이 많이 이루 어지기 때문이다. 또한, 표준화 또는 자동화가 제한적인 경 우가 많아 작업장 재배치 혹은 재설계 같은 일반적인 공학 적 대책이 힘든 경우가 많다(Han et al., 1997). 따라서 공 학적 대책과는 별도로 근골격계 질환의 발생과 진행을 막는 의학적 관리의 필요성이 다른 어떤 업종보다도 중요한 분야 가 된다.

현재 외국과 국내의 자동차 산업은 근골격계 질환의 관리 프로그램이 존재하고 어느 정도 내용이 공개되어 있다(Yoo, 2009). 그러나 국내 굴지의 조선소들은 나름대로 의학적 관 리 체계와 예방 프로그램을 운영하고 있으나 자세한 체계가 잘 알려져 있지 않다. 그리고 중소 규모 조선소들은 경제적 문제 등의 제약 때문에 제한적 의학적 관리만 이루어지는 경 우가 많다. 특히 조선소의 근골격계 질환은 경추, 요추 추간 판탈출증, 회전근개파열, 반월상 연골파열 등 수술을 요하는

Corresponding Author: Young-Ki Kim. Department of Occupational and Environmental Medicine, Pusan National University, Yangsan Hospital, Yangsan, 626-770. Mobile: 010-6858-9321, E-mail: mungis@chol.com

Copyright@2012 by Ergonomics Society of Korea(pISSN:1229-1684 eISSN:2093-8462). All right reserved. 
심각한 상태까지 이르는 경우가 많아(Kim et al., 2005) 재 활치료와 업무복귀 프로그램이 매우 중요하나 이런 프로그 램을 제대로 갖추고 있는 곳은 별로 없다.

따라서 본 논문은 조선업에서 근골격계 질환의 예방과 관 리를 위한 바람직한 의학적 관리 체계 및 프로그램의 내용 을 알아 보고자 한다.

\section{Medical Managements Methods}

일반적으로 의학적 관리를 하는 이유는 질환 예방과 질환 악화를 막는 것이 그 목적이라고 할 수 있다. 그리고 의학적 관리를 하기 위해서는 노동자의 특성과 근로기간, 작업변동 여부, 질병자의 질병 단계에 따라 적절한 접근과 구체적 보 건계획이 수립되어야 한다(Hong et al., 2010; Kim et al., 2005)은 근골격계 질환의 의학적 관리를 질병 단계에 따라 1 단계(무증상기), 2 단계(급성기), 3 단계 (만성기)로 구분하여 각 단계에서 어떤 의학적 관리를 해야 하는지를 기술한 바가 있다. 그러나 본 연구에서는 질병의 자연사 단계에 따른 정 리가 아닌 질병 예방적 원칙과 의학적 관리 체계를 중심으 로 정리하려고 한다. 일반적으로 질병을 예방하기 위해서는 대개 $1,2,3$ 차 예방 원칙을 따른다. 근골격계 질환에서 1 차 예방은 질환이 발생하지 않게 하면서 건강을 증진하는 것이 며 2차 예방은 손상, 질환을 조기에 발견하여 증상악화를 막 는 것이며 3 차 예방은 기존 질환, 손상의 합병증이 발생하 지 않게 하고 조기복귀가 이루어지도록 하는 것이다(Chae et al., 2002). 그리고 이런 목적을 수행하기 위한 체계와 프 로그램 내용이 존재해야 할 것이다. 의학적 관리 체계와 프 로그램은 사업장마다 처한 환경이 달라 일률적으로 정하기 는 어렵지만 주요한 방법들은 공유하는 것이 필요하다.

\subsection{Medical management methods as primary pre- vention}

근골격계 질환의 1 차 예방을 위한 의학적 관리 방법에는 보건교육, 작업능력평가(Work Capacity Evaluation, WCE) 를 통한 적정배치, 건강증진 프로그램 운영 등이 존재할 수 있다.

보건교육은 근골격계 질환에 대한 정의, 근골격계 질환의 종류 및 위험요인, 근골격계 질환의 치료 등과 함께 중량물 취급방법 및 스트레칭, 운동치료 방법 등이 주된 내용이 될 것이다. 특히 이 보건교육은 근골격계 손상의 예방과 근막통 증후군 같은 근육관련 질환을 예방하는 데 효과적이다. 일반 적으로 근막통증후군이 가장 많이 발생하는 부위는 경추 주
위근, 양측 어깨 승모근, 요추 주위근으로서 이 부위의 적절 한 스트레칭과 근력강화운동에 대한 교육을 한다면 효과를 볼 수 있을 것으로 기대가 된다(Blangsted et al., 2008; Daltroy et al., 1997).

작업능력평가를 통한 적정배치는 현실적으로 잘 이루어지 지 않는 상황이며 오히려 왜곡된 측면이 많다. 일반적으로 조선소 같은 중공업 분야는 배치전 검진을 필수적으로 시 행하면서 요추부 방사선 심지어는 요추부 컴퓨터 단층촬영 (Computed Tomography, CT) 까지 촬영하는 곳도 있다. 이 런 검사의 목적은 적절한 배치를 위한 것이 아니라 요추부에 이상이 있는 입사 예정자를 걸러내기 위한 목적으로 사용되 고 있다는 지적이 있었다. 특히 척추분리증(Spondylolysis) 같은 소견이 있는 사람은 정상인과 다름이 없음에도 배치 전 검진에서 탈락하는 불이익을 받는다는 우려가 존재한다. 그러나 이런 영상의학적 이상이 근골격계 질환으로 이어 진다는 결론은 적절하지 못하다는 의견이 많다(Weil et al., 2004). 오히려 배치전 검진의 목적은 적정배치를 위한 것이 므로 근골격계 분야도 적정배치를 위한 고민이 필요하다. 그 를 위해 도입이 필요한 것이 작업능력평가이다. 이 작업능력 평가는 업무적합성 평가, 장애평가, 업무복귀평가(Returnto-work evaluation) 등에서 널리 사용될 수 있는 평가 로서 근골격계 분야는 작업능력평가의 효과를 많이 볼 수 있는 분야이다. 실제 Keith(2006) 등은 503명의 육체적 노동을 주로 해야 하는 신규 입사자를 대상으로 등속성 (Isokinetic) 근력평가를 사용한 배치전 검진을 통해 작업부 하에 따른 적정배치를 한 결과 근골격계 질환과 손상을 의미 있게 줄일 수 있었다고 보고하였다. 이런 작업능력평가는 검 진을 수행하는 기관은 당연히 평가능력을 갖추어야 하며 조 선사업장 내 의료시설에서도 체계를 갖추는 것이 필요하다.

현재 근골격계 질환과 관련하여 조선소에서 운영되는 대 표적인 건강증진 활동은 소위 체력 단련실이라고 불리는 헬 스 운동 시설의 운영이다. 이 체력 단련실은 러닝머신, 자전 거를 비롯하여 여러 가지 근력강화운동 기구를 갖추어 놓고 작업자들이 이용할 수 있도록 하고 있다. 이런 시설이 설치 되는 것은 상당히 긍정적이나 이용시간이 제한적이고 많은 사람이 이용하기에는 공간 및 장비가 부족한 경우가 많은 실 정이다. 그 외에도 일상적인 스트레칭을 시행하는 것도 중요 한 건강증진 활동의 일환이다.

그런데 이런 1차 예방활동의 중요성이 상대적으로 등한시 되는 경향이 있다. 1 차 예방은 질병 발생 자체를 예방하기 위한 활동으로서 가장 중요한 활동임에도 현실적인 제약 때 문에 이루어지지 않는 경우가 많다. 예를 들면 수 만 명이 작업하는 조선소는 전체 작업자를 대상으로 보건교육을 한 다는 것은 결코 쉽지는 않을 것이다. 그러나 전체 작업자를 대상으로 보건교육을 시행하지는 못한다 하더라도 상담실이 


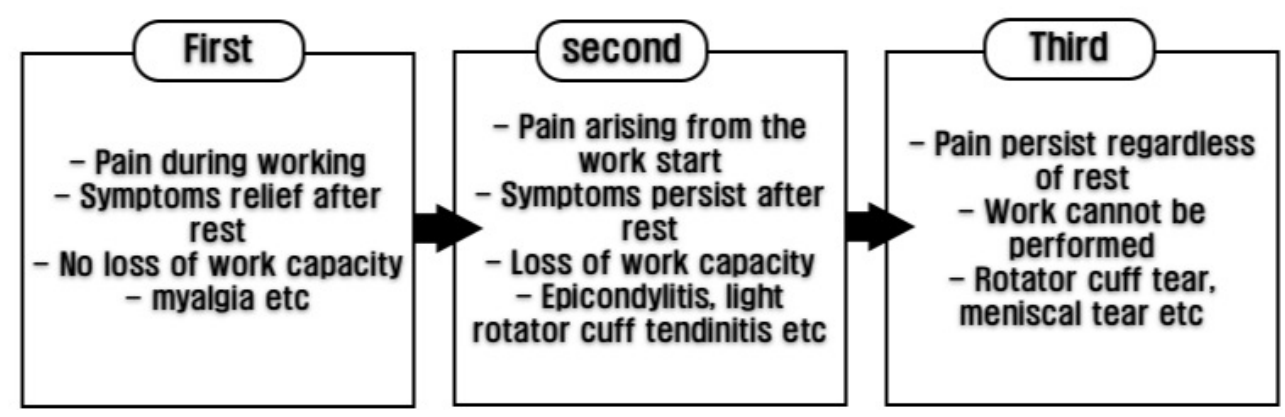

Figure 1. Progress stages of musculoskeletal disorders

나 체력 단련실 등 근골격계 관련 시설을 이용하는 사람들을 대상으로 정기적으로 보건교육을 시행하는 등 접근할 수 있 는 다양한 방법을 고민한다면 불가능한 일은 아닐 것이다. 보건교육만 하더라도 특별한 비용을 들이지 않고도 큰 효과 를 볼 수 있는 경제적인 방법이기도 하다. 스트레칭은 올바 른 방법으로 그리고 적절한 횟수로 시행되지 않는다면 그 효과가 반감이 되며, 대개 작업 시작 전에는 잘 이루어지는 편이나 휴식시간이나 점심시간, 작업 이후에는 하지 않는 경 우가 많으므로 지속적인 교육이 필요하다.

\subsection{Medical management methods as secondary pre- vention}

2차 예방활동은 증상자에 대한 상담, 진단, 치료 등의 과 정으로서 조선 사업장에서 가장 활발하게 이루어지고 있는 부문이다. 대개 의사가 상주하는 산업보건센터에서 증상자 에 대한 상담과 치료 등이 이루어지고 있다. 일부 사업장에 서는 외부 의사가 정기적으로 방문하여 상담하는 자문의 형 태도 존재한다. 그런데 현재의 방식은 증상을 호소하는 사람 에 대해서 상담과 치료가 진행되고 있는 것이 일반적 형태이 다. 근골격계 질환의 발생은 대개 3 단계를 거치게 되는데 (Figure 1), 상담신청을 하는 작업자들은 최소한 2단계의 이상의 증상, 그 중에서도 3 단계에 있는 증상자들이 많다. 이런 현상은 경제적인 문제, 회사 내부의 분위기, 인간관계 등이 원인이 될 것으로 생각하는데 3단계로 진행된 경우 수 술적 치료가 필요할 수 있으며 장애가 남을 수 있으므로 그 만큼 비용과 생산성 손실 측면에서도 바람직하지 못하다. 원 칙적으로 근골격계 질환의 2차 예방에서 가장 중요한 것은 증상자의 조기발견으로서 발병 단계에서 조기발견은 1 단계 에 해당하는 증상자이다. 따라서 증상을 호소하는 사람만 관 리하는 수동적 형태가 아닌 증상자를 조기에 발견할 수 있는 적극적이고 능동적인 체계가 필요하다.

현재 3년마다 유해요인조사가 수행되고 있어 최소 3년에 한 번씩은 증상조사가 진행될 수 있지만 최근 유해요인조사
가 형식적으로 진행되는 경우가 많음을 고려할 때 3 년에 한 번 증상조사가 진행되는 것으로는 근골격계 질환의 조기발 견이 제대로 이루어지지 못할 가능성이 많다. 따라서 사업장 에서는 매년 정기적인 증상조사를 통해 근골격계 증상자를 조기에 발견하기 위한 노력을 기울일 필요가 있다.

Figure 2는 2 차 예방활동을 위한 의학적 관리 체계에 대 한 모식도이다. 일단 증상이 확인된다면 의사의 면담을 통해 질병의 진단과 증상의 정도를 확인하게 되는데 일부 질환들 은 진찰만으로는 진단이 어려운 경우가 많으므로 외부 병원 에 초음파나 $\mathrm{MRI}$, 근전도/신경전도 검사 등을 의뢰하여 확 진을 하는 때도 있다. 진단이 확인된다면 증상의 정도를 확 인하여 근무 중 치료 혹은 휴업치료 결정을 내려야 할 것이 다. 근무 중 치료는 발병 단계 1 단계 혹은 일부 2 단계 환자 로서 약물치료와 함께 사내의 물리치료와 운동치료를 통해 증상완화와 근력강화운동을 시행하게 된다. 그리고 이때는 반드시 보건교육을 같이 실시하여 근골격계 질환에 대한 이 해를 높이고 예방하는 방법, 그리고 안전한 작업방법 등을 앎으로써 이후 근골격계 질환, 손상을 예방하는 데 도움이 될 수 있도록 한다. 또 한가지 유념할 사항은 물리치료나 운 동치료 때 물리치료사나 운동치료사에게 치료의 내용은 일 임한다 하더라도 치료기간, 치료 효과 판정, 복귀 판정은 의 사가 직접 수행해야 한다는 것이다. 그리고 근골격계 위험요 인에 대한 노출시간을 감소시키는 대책으로서 일시적인 잔 업이나 특근의 제한 등 행정적 조치가 고려될 수도 있다. 그 러나 근무 중 치료는 근무시간 중에 1 2시간 정도 치료를 받는 형태로서 치료 이후 다시 작업을 수행해야 하므로 치 료 효과가 반감되므로 인해 치료기간이 길어지는 경우가 많 다. 그리고 일부 질환은 물리치료와 약물치료만으로는 증상 완화가 충분치 못하므로 주사치료 등의 전문치료를 요하는 상황이 발생할 수 있다. 여기서 전문치료는 주로 근육 내 자극치료 (IntraMuscular Stimulation, IMS), 통증점 주사 (Trigger Point Injection, TPI) 같은 비교적 간단한 시술 로서 외상과염이나 경한 회전근개 건염, 수근관증후군, 근막 통증후군 같은 질환에서 효과적이다. 이런 전문치료는 사내 


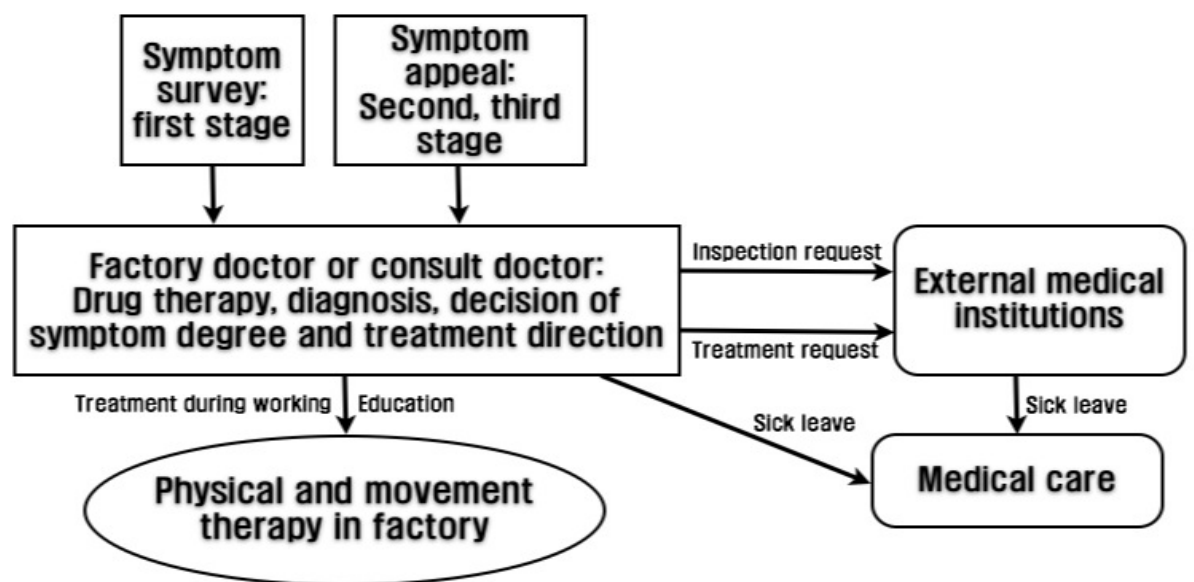

Figure 2. Secondary medical prevention systems

의 의료시설에서 의사가 직접 시행할 수도 있으나 그렇지 못한 상황이라면 외부 병원에 의뢰해야 하며 그를 위해 필 요한 체계, 즉 치료비용, 근무시간 할애 문제 등에 대한 내 부적 지침을 만들 필요가 있다.

한편, 휴업치료는 사내의 근무 중 치료만으로는 치료 효과 를 보기 어렵다고 판단되는 경우에 작업하지 않는 상태에서 치료를 받는 것을 말하며 대개 2,3 단계 증상에 해당하는 환 자들이다. 여기서 휴업치료는 기본적으로 산재요양치료를 말 하지만, 일부 사업장은 회사에서 치료비 등을 부담하고 치료 기간 동안의 임금도 지급되는 소위 공상치료라는 형태가 존 재한다.

특히 근골격계 질환은 산업재해보상보험(산재)에 따른 산 재요양을 신청하기보다는 공상치료로 가는 경우가 더 많다. 그것은 노동자들의 입장에서도 산재요양보다는 공상치료가 경제적으로 유리할 수 있고, 산재처리 절차의 번거로움이 없 으며 회사의 회유를 거절하기 어려운 점 등이 작용하며(Kim, 1998; Yang, 1998), 또한 최근에는 산재 불승인율의 증가 때문에 산재요양 신청 자체를 꺼리는 것이 원인인 것으로 추 정된다. 따라서 회사 내에 의사를 고용하고 치료시설을 만드 는 의학적 관리 체계가 산재신청이 아닌 공상신청을 유도 하여 산재은폐 수단으로 이용되고 있다는 비판도 존재한다 (Korean labor safety and health agency, 2003). 그러나 모 자동차회사는 노동조합에서 공식적인 공상치료체계를 요 구하여 시행되고 있는 것처럼 의학적 관리 체계 자체보다는 그것을 운영하는 과정의 문제가 더 현실적이고 중요한 문제 가 될 것이다.

한편, 회사 경영 여건상 회사 내에 의사를 선임하거나 사 내 치료시설 등을 두기 어려운 중소 조선소도 최소한 정기 증상조사와 증상호소 보고체계는 기본적으로 마련해야 한다. 그리고 증상자에 대해서는 외부 병원에 의뢰하고 외부 병원
의사가 근무 중 치료와 휴업치료 등의 치료방향을 결정하도 록 하는 체계 마련이 필요하다.

또한, 2 차 예방활동과 관련하여 한 가지 고려할 사항은 사 내 협력업체의 문제이다. 현재 대부분 조선소에서 사내 협력 업체 노동자 수는 직영 노동자보다 많으며 더 힘든 작업, 열 악한 작업에 종사하는 경우가 많아 근골격계 질환이나 손상 의 발생위험이 높다(Shin et al., 2008). 따라서 비록 협력 업체는 회사가 직영회사와는 독립적으로 존재하지만, 조선소 내에서 작업하므로 사내 치료시설을 이용하는 데 있어서 직 영 노동자와 같은 기회를 가질 수 있도록 할 필요가 있다.

\subsection{Medical management methods as tertiary pre- vention}

앞서 기술한 것처럼 조선업에서 근골격계 질환과 손상은 수술을 요하는 심한 경우가 많으므로 재활치료가 매우 중요 하다. 일반적으로 같은 질환에 대해 산재요양 기간이 건강보 험이나 자동차보험보다도 길지만, 조선업에서는 더 긴 것으 로 알려져 있다(Kim et al., 2004; Chae et al., 2002). 이런 요양기간이 장기화하는 이유는 몇 가지 원인이 있을 수 있겠 다. 첫째는 증상자 조기발견이 잘 안 되는 것이다. 2 차 예방 활동에서 대부분 조선소에서는 조기발견 시스템이 없고 많 은 작업자가 이미 장기간 요양이 필요한 3단계 상태에서 상 담신청을 하게 된다. 둘째, 현행 산재보상제도는 치료 중심 으로 조기업무복귀를 위한 재활 프로그램이 제대로 없는 실 정이다. 또한, 조기복귀를 유도할 수 있는 동기 부여도 없다 (Chae et al., 2002). 따라서 조기복귀를 가져올 수 있는 재 활 프로그램, 조기복귀 프로그램을 사업장 의학적 관리 체계 에 마련하는 것은 3 차 예방활동의 핵심적 내용이 될 것이다. 그런데 재활치료와 관련해서 생각해야 할 부분은 근골격 


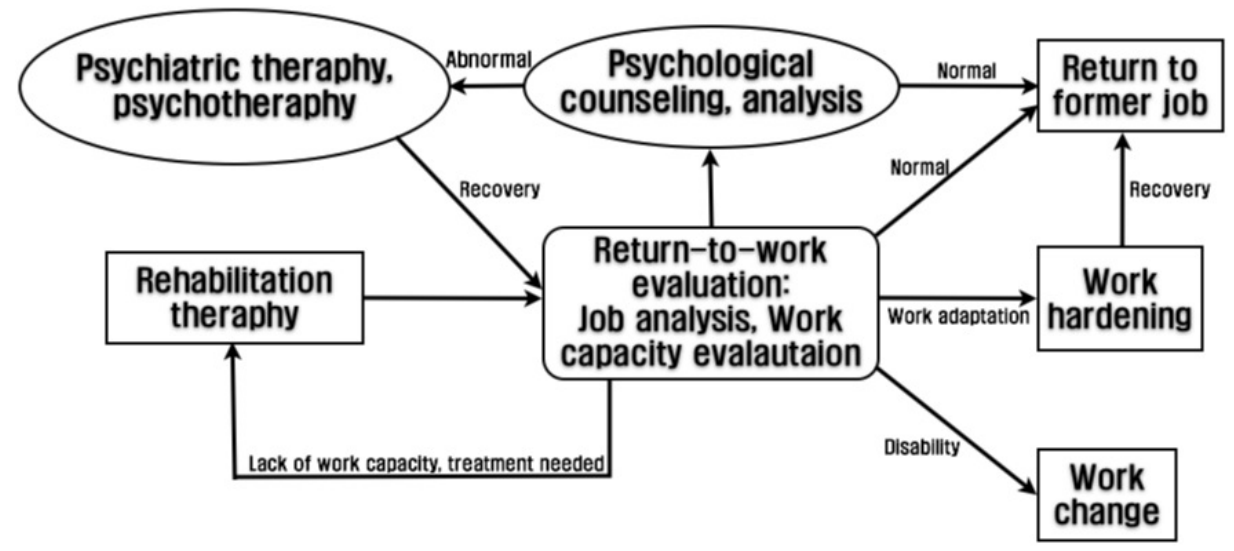

Figure 3. Tertiary medical prevention systems

계 질환의 치료과정의 문제이다. 치료를 담당하는 의사들은 대부분 정형외과나 신경외과 의사들인데 이런 외과 의사들 의 주된 관심은 통증으로써, 통증이 없어지면 치료가 다 되 었다고 생각하는 경향이 있다. 그러나 요양치료 때문에 장기 간 작업을 쉬었을 때 작업 시 사용했던 근육이 퇴화하고 근 력이 감소하므로 재활운동을 통해 아프기 전 상태로 회복하 지 않는다면 복귀 후 수개월 내에 증상의 재발생 혹은 새로 운 근골격계 손상이 발생할 수 있다.

따라서 요양치료를 받는 환자는 외부 병원 의사에게 모 든 치료를 맡기는 것이 아니라 사내 의사가 정기적으로 상 담하여 재활치료 상황을 점검하고 조기복귀에 대한 필요성 과 조기복귀의지를 주지시키는 것이 중요하다(Cheng et al., 2007). 특히 외부 병원에서 적절한 재활치료를 받고 있지 못하다면 사내에서 재활치료가 이루어질 수 있도록 할 필요 가 있다.

요양종결 시점이 다가온다면 종결 전에 업무복귀가 가능 한가를 평가하기 위해서는 해당 환자의 업무분석과 작업능 력평가를 실시해야 하는데 이런 과정을 업무복귀평가라 부 르기도 한다. 업무복귀과정에서 실시하는 작업능력평가는 특 히 객관적인 결과를 요구하는 경우가 많다. 왜냐하면, 여러 가지 이유로 자신들의 증상, 상태를 과장 혹은 축소하여 요 양기간을 연장 혹은 감소시키려는 요구가 현실적으로 존재 하기 때문이다. 따라서 업무복귀평가 때에는 컴퓨터화된 장 비를 사용하면 일정 정도 작업능력상태를 객관화하는 데 도 움이 될 수 있다(Matheson, 2003; King et al., 1998). 현 재 우리나라에 보급된 컴퓨터화된 작업능력평가 장비는 몇 가지가 있는데 대표적인 장비는 Primus RS, Biodex, Cybex 등이 있다. 각각의 장비는 장단점이 있는데 예를 들면 Primus $\mathrm{RS}$ 의 경우 상, 하지 능력평가는 우수하나 요추부 근력평가 는 불편한 측면이 있는 반면에 Biodex의 경우 요추부와 하 지의 평가는 쉽나 상지의 평가는 제한적이다. 그리고 이런
장비들 사용하기 위해서는 장비의 신뢰도, 타당도가 인정받 는 것이 필수적인데 Primus RS의 경우 주요한 도구들이 타당도와 신뢰도가 높은 것으로 알려져 있다(Innes et al., 1999).

업무복귀평가를 통해 증상이 있기 전 작업상태를 수행할 수 있는 능력이 확인된다면 원직으로 업무복귀를 해야 하지 만, 만일 그렇지 못하다면 여러 가지 고려해야 할 것들이 있 다. 아직 통증, 운동제한 등의 의학적 증상이 남아 있어 재활 치료가 더 필요하다면 일정기간 재활치료기간을 연장해야 하 고, 증상은 없으나 근력이 약간 떨어지는 상태를 보인다면 원직 복귀보다는 현장에서 부담되지 않는 범위내에서 가능한 작업부터 시작하여 업무적응력을 높이는 방식이 필요할 수 있다. 그리고 만일 업무복귀평가에서 원직을 수행할 수 없는 장애 등이 존재하는 것이 확인된다면 작업전환을 통해 장애 문제를 해결할 수 있도록 노력할 필요가 있다(Figure 3).

\subsection{Managements for psychological factors}

근골격계 질환으로 인한 요양치료, 특히 산재요양 과정 중 에 당사자는 심한 심리적 스트레스를 겪을 수 있다. 산재요 양과정에서 휴업급여의 $70 \%$ 만 지급받고, 산재보험에서는 급 여로 인정되지 않는 치료가 많으므로 산재환자들은 경제적 고통에 처할 가능성이 많고, 또한 치료에도 만성적인 신체증 상, 혹은 손상이 남으면 이 때문에 정신적 고통이 심할 수 있다(Cha et al., 1986). 산재환자에 있어서 산재는 또 하 나의 외상으로서 이런 정신적 고통 때문에 외상 후 스트레 스 장애나 우울증 같은 정신질환으로까지 진행될 수 있다. $\operatorname{Kim}(2001)$ 등은 169 명의 산재환자와 166 명의 일반 노동 자를 대상으로 한 환자대조군 연구에서 산재 환자군이 대조 군과 비교하면 삶의 질 척도가 유의하게 낮았으며, 자살사고 와 우울증상이 유의하게 높다고 보고하였다. 그리고 치료기 
간이 길수록 자살사고의 위험이 높다고 하였다. 한편, 일부 산재환자들은 자살이라는 극단적 선택까지 하는 경우가 있 다. $\operatorname{Kim}(2007)$ 등은 1998년부터 2001년까지 산재요양을 받은 255,166명을 대상으로 1998 년부터 7 년간 추적 관찰 한 결과 산재환자의 자살을 일반인구집단의 자살과 비교하 였을 때 SMR이 1.73(1.55 1.93)을 보였고, 요양이 기간 이 길수록, 장애등급이 높을수록, 사업장 규모가 작을수록 자살위험이 높았다고 보고하였다. 따라서 산재요양 등 장기 간 요양치료를 하는 사람들은 치료기간 동안 심리적 상태에 대한 점검을 받고 관리가 될 수 있도록 하는 체계가 필요하 다. 특히 심리적 스트레스는 복귀시점에 가장 심할 가능성 이 높은데 그 이유는 복귀시점을 두고 의사와 환자 간에 이견이 많이 발생하고 산재요양일 때 환자의 상태가 점검되 지 못한 상태에서 강제 종결되는 경우가 많기 때문이다. 따 라서 복귀시점에서는 반드시 환자의 심리상담 등을 통해 심 리문제가 있는지를 살펴야 하며 이런 과정이 복귀 프로그램 에 포함될 수 있도록 해야 한다(Figure 3).

여기까지 조선업에서 의학적 관리방안에 대해 살펴보았는 데 잊지 말아야 할 것은 의학적 관리 단독으로는 근골격계 질환을 근본적으로 예방할 수 없다는 것이다. 오히려 의학적 관리는 보조적 수단이며 인간공학적 관리대책이 근본적 예 방방법이 될 것이다. 조기업무복귀를 방해하는 요인이 여러 가지가 있는데 자신을 아프게 만든 현장이 개선되지 않은 것 에 대한 불안감이 주요한 원인 중 하나이며, 자신의 작업 개 선작업에 참여하는 것이 조기복귀를 하는 데 도움이 되는 것 을 볼 때(Duijn et al., 2004), 인간공학적 개선이 의학적 관 리와 함께 연계되어 이루어진다면 훨씬 바람직한 결과를 가 져올 수 있을 것으로 기대된다.

\section{Conculusion}

조선업에서 근골격계 질환은 발생위험이 높은 만큼 예방 을 위한 시도는 큰 의미가 있다. 1 차 예방은 보건교육, 작업 능력평가를 통한 적정배치, 스트레칭 등의 건강증진운동이 있으며 2차 예방은 증상자의 조기발견과 적절한 치료가 이 루어질 수 있는 체계를 구성하는 것이며 3 차 예방은 재활치 료와 함께 업무복귀평가를 통한 조기복귀를 꾀하는 것이다. 그리고 장기간의 요양은 심리적 문제를 일으킬 가능성이 높 으므로 복귀시스템 내에는 심리 상담 등의 프로그램도 같이 배치하여 관리하는 것이 중요하다. 마지막으로 의학적 관리 는 근골격계 질환을 예방하는데 이바지를 할 수 있지만, 인 간공학적 대책과 개선과 같이 이루어질 때 훨씬 효과가 클 것으로 생각한다.

\section{Acknowledgements}

This study was supported by a grant(2010) from Pusan National University, Yangsan Hospital, Yangsan, Korea.

\section{References}

Blangsted, A. K., Soggard, K., Hansen, E. A., Hannerz, H. and Sjogaard, G., One-year randomized controlled trial with different physical activity programs to reduce musculoskeletal symptoms in the neck and shoulder among office workers. Scand J Work Environ Health, 34(1), 55-65, 2008.

Cha, B. S. and Park, J. K., Mental health status among users of medical 7 facilities in mining area. J Prev Med Public Health, 19(2), 233-243, 1986.

Chae, H. J., Lee, S. K., Lee, K. J. and Moon, J. D., Characteristics of work-related musculoskeletal disorders and effect of intervention program in shipyard workers. Korean J Occup Environ Med, 14(4), 468-477, 2002

Cheng, A. K. and Hung, L. K., Randomized controlled trial of workplacebased rehabilitation for work-related rotator cuff disorder. $J$ Occup Rehabil, 17, 487-503, 2007.

Daltroy, L. H., Larson, M. G., Lew, R., Wright, E., Ryan, J., et al. A controlled trial of an educational program to prevent low back injuries. N Eng J Med, 337(5), 322-328, 1997.

Duijn, M., Miedema, H., Elders, L. and Burdorf, A., Barriers for early return-to-work of workers with musculoskeletal disorders according to occupational health physicians and human resource managers. $J$ Occup Rehabil, 14(1), 31-41, 2004.

Han, S. H., Baek, N. J., Park, D. H., Jang, K. E., Lee, M. H., et al. Cumulative trauma disorders among shipyard workers and application of baseline checklist for risk assessment. Korean J Occup Environ Med, 9(4), 579-588, 1997.

Hong, J. Y. and Koo, J. W., Medical approach of work-related musculoskeletal diseases. J Ergon Soc Korea, 29(4), 473-478, 2010.

Innes, E. and Straker, L., Reliability of work-related assessments, Work, 13, 107-124, 1999.

Keith, E. R. and Arti, S. A., study of the effects of isokinetic pre-employment physical capability screening in the reduction of musculoskeletal disorders in a labor intensive work environment, Work, 26(2), 215 $-228,2006$.

Kim, H. R., Ahn, Y. S. and Koh, D. H., Suicide level of occupational injuries in Korea. Korean Society of Occupational \& Environmental Medicine Autumn Conference Presentation book, pp341, Busan, 2007.

Kim, I. A., Koh, S. B., Kim, J. S., Kang, D. M., Son, M. A., et al. The Relationship between Musculoskeletal Symptoms and Job Stress \& Intensity of Labor among Shipbuilding Workers. Korean J Occup Environ Med, 16(4), 401-412, 2004. 
Kim, J. E., Kang, D. M., Shin, Y. C., Son, M. A., Kim, J. W., et al. Risk factors of work - related musculoskeletal symptoms among ship-yard workers. Korean J Occup Environ Med, 15(4), 401-410, 2003.

Kim, J. Y., Lim, H. S., Moon, J. D., Lee, C. R., Lee, Y. H., et al. Study for appropriate sick leave periods of work-related musculoskeletal disorders, pp3-69, Dong-A University, Busan, 2004.

Kim, S. I., Yun, K. W., Ha, E. H., Woo, H. W. and Kim Y. C., Quality of life, suicide ideation and depressive symptoms industrial injury patients. J Neuropsychiatr Assoc, 50(3), 416-424, 2001.

Kim, S. K., A status of the report for industrial injuries and illness at an automobile related plants. Korean J Occup Environ Med, 10(4), 562 $-570,1998$

Kim, S. W., Shin, Y. C. and Kang, D. M., Characteristics of work-related musculoskeletal disorders compensated by the industrial accidents compensation insurance in shipbuilding industry. J Korean Soc Occup Environ Hyg, 15(2), 114-123, 2005(Korean).

Kim, Y. H., Lee, C. R., Lee, J. H., Lee, H. and Hwang, C. H., Study for occupational medical management model of work related diseases, pp7-59, Occupational health and safety research institute, Incheon, 2005.

King, P., Tuckwell, N. and Barrett, T., A critical review of functional capacity evaluations. Physical Theraphy, 78(8), 852-866, 1998

Korean labor safety and health research agency, No true prevention in musculoskeletal disorders, Korean labor safety and health research agency, http://kilsh.or.kr/bbs/zboard.php

Matheson, L. N., The functional capacity evaluation, In G. Andersson \& S. Demeter(ed), Disability Evaluation, Mosby, Chicago, 1-35, 2003.

Ministry of employment and labor, Industrial accidents incidence statistics, pp7-14, Ministry of employment and labor, Seoul, 2010.

Shin, S. H., Kim, D. H., Ahn, J. H., Kim, H. D., Kim, J. H., et al. Factors associated with occupational injuries of ship-building supply workers in Busan. Korean J Occup Environ Med, 20(1), 15-24, 2008.

Weil, L., Weil, D., Dochin, M., Mann, G. and Hasharoni, A., Correlation between pre-employment screening X-ray finding of spondylolysis and sickness absenteeism due to low back pain among policemen of the Israeli police force. Spine, 29(19), 2168-2172, 2004.

U.S. Bureau of Labor Statistics, Industry injury and illness data-2000, Washinton D.C., U.S. Bureau of Labor Statistics, 2001.
Yang, K. S., For occupational health policy. Labor and health, 52, 75-79, 1998.

Yoo, H. J., Evaluation of the efficiency of medical management program for musculoskeletal disorders and suggestion for improvement, Industrial management and design graduate school master paper. pp1-8. Han-Yang University, Seoul, 2009.

\section{Author listings}

Jong Eun Kim: kim-jongeun@hanmail.net

Highest degree: Master, Medical Graduate School, Inje University Position title: Assistant Professor, Department of Occupational and Environmental Medicine, Pusan National University, Yangsan Hospital Areas of interest: Musculoskeletal Disorder, Medical Treatment

\section{Young Ki Kim: mungis@chol.com}

Highest degree: $\mathrm{PhD}$, Medical Graduate School, Inje University Position title: Assistant Professor, Department of Occupational and Environmental Medicine, Pusan National University, Yangsan Hospital Areas of interest: Musculoskeletal Disorder, Return-to-Work

Dong Mug Kang: kangdm@pusan.ac.kr

Highest degree: $\mathrm{PhD}$, Medical Graduate School, Kosin University Position title: Associate Professor, Department of Occupational and Environmental Medicine, Pusan National University, Yangsan Hospital Areas of interest: Asbestosis, Risk Factor Research

Date Received : 2011-12-27

Date Revised :2012-01-10

Date Accepted : 2012-01-17 